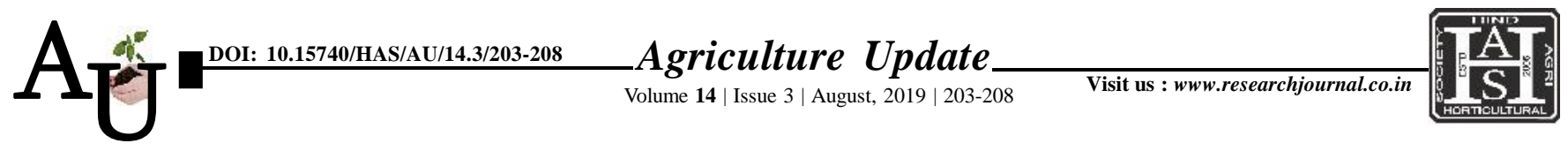

ISSN-0973-1520

\title{
Research article: Personal, socio-economic and psychological characteristics of farm women
}

\author{
J. I. Shaikh, S. B. Shinde and M. C. Ahire
}

Article Chronicle:

Received :

07.06.2019;

Revised :

01.07.2019;

Accepted :

11.07.2019

KeY Words :

Farm women

SUMMARY : The international development community has recognized that the agriculture is an engine of growth and poverty reduction in countries where it is the main occupation of the poor. But the agriculture sector in many developing countries is underperforming, in part because women, who represent a crucial resource in agriculture and the rural economy through their roles as farmers, labourers and entrepreneurs, almost everywhere face more severe constraints than men in access to productive resources. The analysis of personal, socio-economic and psychological characteristics of the women revealed that majority of them were middle age, has primary education, were married, had agriculture as major occupation, belonged to nuclear families of medium size, had medium experience in farming, dairying, goat rearing and poultry management had medium social participation, medium information seeking behaviour, small land holding, medium annual income and medium achievement motivation.

How to cite this article : Shaikh, J. I., Shinde, S.B. and Ahire, M.C. (2019). Personal, socio-economic and psychological characteristics of farm women. Agric. Update, 14(3): 203-208; DOI : 10.15740/HAS/AU/14.3/ 203-208. Copyright@ 2019: Hind Agri-Horticultural Society.

Author for correspondence :

\section{J. I. Shaikh}

Department of Extension Education, Mahatma

Phule Krishi Vidyapeeth, Rahuri, Ahmed Nagar

(M.S.) India

Email: mehjabin1323@ gmail.com

See end of the article for authors' affiliations 